\title{
Minority Shareholdings in European Union Merger Control
}

\author{
Jeaneth Michelle L. Balaba \\ University of the City Of Manila Intramuros, Manila, Philippines
}

\begin{abstract}
From the perspective of competition policy, which looks into how the competitive field in industry markets are enhanced or threatened, mergers and acquisitions are closely observed especially with regard to how they disrupt the level playing field of otherwise competitive industries. That is, there are laws in many countries that enforce anti-trust competition policies and the application of these policies are strictly enforced in many major mergers and acquisitions in market-based nation-state economies and regional economies such as the European Union and its component countries. This research looks into merger control in the European Union and the important focus that the EU has put on minority shareholdings in mergers and acquisitions and full joint ventures. Specifically, the central issue is the lack of mechanism at the EU level to effectively deal with undue decisive influence that minority shareholdings bring to the table of merger strategic, and therefore, competitive decisionmaking.
\end{abstract}

KeyWords: Merger control, minority shareholdings, European Union, Merger Regulation

\section{Minority Shareholdings in European Union Merger Control}

\section{INTRODUCTION}

Mergers, acquisitions and joint ventures are three of the different ways by which a business enterprise may structure or restructure its organizations in response to changing market dynamics or business organizational thrusts, such as expansion into new markets or attaining scale efficiencies to improve profitability. Mergers may also enhance technological progress by promoting the diffusion of technology or increasing the incentives for research and development activities. ${ }^{1}$ In general, mergers of businesses mean a reduction of players in an industry (that is, there is some concentration of businesses) and this has implications on the industry output, (higher) prices of goods or services or even (diminished) incentive to innovate as the market becomes more concentrated. ${ }^{2}$

A merger is a structural or organizational integration of two firms that result in a common ownership and management structure. Mergers are executed typically through stock swaps. An acquisition is a type of merger in which a firm with more resources and market strength may acquire another firm through a combination of equity infusion (purchase of stocks) or debt for equity swaps. On the other hand, a joint venture is a strategic business alliance where two firms share resources, equity, revenues, expenses and management to pursue a common goal.

\footnotetext{
${ }^{1}$ European Commission, The Efficiency Defence and the European System of Merger Control (European Economy, Reports and Studies, European Union, 2001)

${ }^{2}$ John Rill and others, Coordinated Effects Analysis Under International Merger Regimes (ICN, 2004)
} 
Each firm retains its own corporate identity in a joint venture, even as that joint venture has its own corporate identity.

Mergers can be horizontal or vertical integration of businesses. Horizontal integration brings together competitor firms into a single enterprise and essentially implies reduced market competition with attendant market dominance concerns (monopoly hold or oligopoly power of few dominant firms). Vertical integration essentially consolidates in one enterprise those firms which have customer-supplier relationships. ${ }^{3}$

From the viewpoint of competition policy, which looks into how the competitive field in industry markets are enhanced or threatened, mergers and acquisitions are closely observed especially with regard to how they disrupt the level playing field of otherwise competitive industries. That is, there are laws in many countries that enforce anti-trust competition policies and the application of these policies are strictly enforced in many major mergers and acquisitions in market-based nation-state economies and regional economies such as the European Union and its component countries. This research looks into merger control in the European Union and the important focus that the EU has put on minority shareholdings in mergers and acquisitions and full joint ventures. Specifically, the central issue is the lack of mechanism at the EU level to effectively deal with undue decisive influence that minority shareholdings bring to the table of merger strategic, and therefore, competitive decisionmaking.

\section{Merger Control Overview}

Competition policy, especially anti-trust laws which relate to the regulation of industry market structures in order to delimit the ill effects of monopolies and oligopolies, commonly provide for the control or even the consummation of merger transactions. The regulatory function is often performed by national (such as the US or EU member-states) or supra-national bodies which give the go-signal for mergers to take place or to effectively block such mergers when these organizational integrations result in eliminating competition or are disadvantageous to public interest. ${ }^{4}$ Merger control is the process of reviewing mergers and acquisitions and their compatibility or compliance to the provisions and intent of anti-trust or competition law. More than 100 countries now have a form of merger control review where mergers and acquisitions come under close scrutiny when these are perceived to be inimical to public interest and subverting anti-trust provisions of existing laws.

Merger control reviews are entrusted to national or supra-national regulatory bodies such as the U.S. Federal Trade Commission and the EU European Commission which oversee merger control regimes instituted to block the anti-competitive effects of industry concentrations (referring to the few-ness of players in a particular industry) that mergers and acquisitions may bring. That said, most merger control regimes follow exhaustive analysis and procedures to perform any of the following evaluative tests: ${ }^{5}$

- Whether the concentration significantly impedes effective competition (European Union)

- Whether the concentration substantially lessens competition (United States, United Kingdom)

\footnotetext{
${ }^{3}$ ICT Regulation Toolkit, Anti-Competitive Conduct (infoDev, 2014)

4 OECD, Anti-Trust Issues Involving Minority Shareholdings and Interlocking Directorates, (OECD DAF/COMP(2008)30, 2009)

${ }^{5}$ Wikipedia, Merger Control (wikipedia, 2013) 
- Whether the concentration leads to the creation of a dominant position within the industry (Germany, Switzerland)

According to the International Competition Network (ICN), the acquisition of shares or other ownership interests such as partnership equity interest or LLC equity are considered as mergers that may qualify for merger review purposes if this results in an acquisition of control of the target company. Under merger control regimes, a prospective merger review is in order whenever the buyer obtains a controlling equity interest in the target company such that it can exercise a decisive influence over the target's business operations. On the other hand, an acquisition of control is presumed to arise whenever the buyer acquires a majority of the target company's shares, allowing the buyer voting rights through which it influences the target's corporate board, management and/or strategic direction.

\section{Rationale for Merger Control in the EU}

Globalization and the dismantling of non-tariff barriers have had significant roles in the emergence of a system of merger control in the EU. The rise of regionalised and integrated and single market economies, of which the EU has been a model for other world regions, resulted major corproate reorganisations within the EU, particularly in the form of cross-border mergers. ${ }^{6}$ Within the European Community, the European Commission was given specific powers to control mergers having an EU or Community dimension. Even without such an EU dimension, the powers of the European Commission to render prohibitions against the operation of proposed mergers may extend in extraordinary circumstances.

\section{European Commission Merger Regulation}

The European Commission Merger Regulation (EMR) is the European Union's principal legal instrument for the control of mergers and acquisition at the EU or Community level. The European Commission is tasked with the authority to implement the regulations governing merger control and merger reviews for qualified threshold and geographic coverage cases. ${ }^{7}$ All other significant merger cases that do not qualify as having an EU or Community dimension are within the jurisdiction of the respective National Competition Authorities (NCAs). That is, NCAs retain merger control jurisdiction over merger proposals that fall below the turnover thresholds set forth in the EMR. In some cases, where a number of NCAs are involved, a merger case may be referred to the European Commission for resolution.

Adopted in 1989, the current amended version of this Regulation was enforced on May 1, 2004..$^{8}$ The EMR allows the European Commission the authority to control and conduct merger control reviews on certain concentrations (mergers or acquisitions) that meet the relevant jurisdictional threshold tests. Only when the European Commission has done its investigation and stamped its approval of the merger shall such merger transactions be put into effect within the scope of the EU. However, the EMR also grants that when a merger transaction does not have the EU dimension, these transactions may in turn be scrutinized by national competition agencies (NCAs) under national merger control rules. ${ }^{9}$

\footnotetext{
${ }^{6}$ European Commission DG Economic and Financial Affairs, Mergers and Acquisitions Note (European Commission, 2005)

${ }^{7}$ Council Regulation (EC) No 139/2004 on the Control of Concentrations Between Undertakings (the EC Merger Regulation), 2004 OJEU Series L 24/1, 2004

${ }^{8}$ Slaughter and May, The EU Merger Regulation: an Overview of the European Merger Control Rules (Slaughter and May, 2012)

${ }^{9}$ Council Regulation (EC) No 139/2004 on the Control of Concentrations Between Undertakings (the EC Merger Regulation), 2004 OJEU Series L 24/1, 2004 (EC Merger Regulation)
} 
Under the EMR, merger or joint venture transactions have an EU dimension when certain turnover or revenue thresholds are met, namely:

(1) according to the original thresholds set in 1989 which applies the concept of one-stop shopping at the EU level to any merger deal that meets any of the following tests: ${ }^{10}$

A. Worldwide turnover threshold where the combined worldwide turnover of all the undertakings concerned must be more than 5 billion euros;

B. EU-wide turnover test where each of at least two of the undertakings concerned must have EU-wide turnover of more than 250 million euros;

C. Two-thirds rule where a concentration or merger transaction does not have an EU dimension if each of the undertakings concerned achieved more than two-thirds of its EU-wide turnover in one and the same EU member-state.

(2) according to alternative thresholds that seek to extend the one-stop shop EU principle to those transactions what would be evaluated for merge control review by three or more NCAs in the EU; these thresholds evaluate those deals that do not meet the original thresholds as still having an EU dimension if they meet all of the following tests: ${ }^{11}$

A. Lower worldwide turnover threshold with combined worldwide turnover of all the undertakings concerned of more than 2.5 billion euros;

B. Lower EU-wide turnover test where each of at least two of the undertakings concerned must have EU-wide turnover of more than 100 million euros;

(3) Three member-states threshold: In each of at least three EU member-states,

A. The combined national turnover of all the undertakings concerned is more than 100 million euros; and

B. Each of at least two of the undertakings concerned has a national turnover of more than 25 million euros; and

Two-thirds rule: A merger transaction does not have an EU dimension if each of the undertakings concerned achieved more than two-thirds of its EU-wide turnover in one and the same EU member-state.

Under the EMR, joint venture transactions may be covered my merger control reviews when they display structural merger characteristics such as when the venture between two or more companies allow the venture undertaking itself to take over part of its parent company's existing activities or it may represent a new start-up venture. ${ }^{12}$ In which case, such full function joint ventures need to notify to the European Commission under the EMR if these ventures have an EU dimension. Joint ventures that do not fall under the EMR regime may still be reviewed under the general Articles 101 and 102 procedures, to include the benefit of obtaining the European Commission's block exemption when it is deemed that the transaction is actually pro-competitive and beneficial to consumers. ${ }^{13}$ When such joint venture or strategic alliance is not covered under the EMR and also does not qualify for a block exemption, the parties to the undertaking need to consider whether the proposed transaction (1) significantly

\footnotetext{
${ }^{10}$ EC Merger Regulation

${ }^{11}$ Council Regulation (EC) No 139/2004 on the Control of Concentrations Between Undertakings (the EC Merger Regulation), 2004 OJEU Series L 24/1, 2004

${ }^{12}$ Slaughter and May, The EU Merger Regulation: an Overview of the European Merger Control Rules (Slaughter and May, 2012)

${ }^{13}$ Slaughter and May, The EU Merger Regulation: an Overview of the European Merger Control Rules (Slaughter and May, 2012)
} 
restricts the competition that would have existed between the parties either at the research and development, production or manufacturing and/or commercialisation or supply stages, (2) appreciably affects the competitive position of third parties (suppliers, customers or competitors), or (3) forms part of a wider network of cooperation between the parties or with third parties, especially if in highly concentrated markets with very few sellers. ${ }^{14}$

\section{Articles 101 and 102 of the Treaty on the Functioning of the European Union}

The rules of competition in the EU and among its member-states are outlined in the Treaty on the Functioning of the European Union (TFEU) which, as amended and consolidated with the Treaty of the European Union (TEU), comprises what is commonly known as the Lisbon Treaty. Specifically, reference is made to Articles 101 of the TFEU which explicitly identifies the conditions which merit the prohibition of merger agreements or concerted practices that restrict or distort competition within the EU market. However, Article 1 of the TFEU does grant the prohibition inapplicabe when such merger transactions or agreements of undertakings contribute to improving the production or distribution of goods or promote technical or economic progress. ${ }^{15}$

Under Article 1, the following transactions are deemed incompatible with the workings of the internal market, when these are included or a result of any or all agreements between undertakings, decisions by associations of undertakings and concerted practices which affect trade between EU Member-States and which have as their intent or effect to prevent, restrict or distort competition within the integrated regional market:

1) Direct or indirect fixing of the buying or selling price;

Controlling or limiting the production, markets, technical development or investment in the industry;

2) Sharing of markets or sources of supply;

3) Creating competitive disadvantage for other trading parties through trade discrimination on equivalent transactions;

4) Making contracts conditional to the acceptance by other parties of supplementary obligations that are unrelated to such contracts.

On the other hand, Article 102 prohibits undertakings that constitute an abuse of a dominant position within the EU market or in a substantial part of it. Abuse of dominant position may consist in any of the following:

1) Direct or indirect fixing of the buying or selling price or other unfair trade practices;

2) Controlling or limiting the production, markets, technical development or investment in the industry;

3) Creating competitive disadvantage for other trading parties through trade discrimination on equivalent transactions;

4) Making the conclusion of contracts subject to the acceptance by other parties of supplementary obligation which have no connection with the subject of such contracts.

\section{Block Exemptions under the EC Merger Regulation}

The merger block exemptions provided in the EC Member Regulation are derived from the provisions of the Articles 101 and 102 procedures set forth in the TFEU. When the Articles 101 and 102 procedures apply, the European Commission may issue a block to prevent the

\footnotetext{
${ }^{14}$ Slaughter and May, The EU Merger Regulation: an Overview of the European Merger Control Rules (Slaughter and May, 2012)

${ }^{15}$ Consolidated Version of the Treaty on European Union and the Treaty on the Functioning of the European Union, 2012, OJEU Series C326/01, 2012
} 
consummation or operation of the merger within the EU. However, there are four conditions that allow a block exemption to be granted by the European Commission ${ }^{16}$, and these occur when: ${ }^{17}$

1) The merger transaction contributes to improving the production or distribution of goods or to promote technical or economic progress;

2) The merger allows its consumers a fair share of the resulting benefit;

3) The merger does not impose restrictions that are not indispensable to the attainment of (a) or (b); and

4) The merger does not afford the possibility of eliminating competition in respect of a substantial part of the products in question.

\section{The Concept of Industry Concentration and Management Control in the EU}

According to established economic theory, the degree of concentration in an industry's market structure depends on the number of players that serve that particular market. A highlyconcentrated industry is characterised by the presence of very few players or some form of oligopolistic or even a monopoly type of market structure. Clearly, competition policies are wary of highly-concentrated industries because any effort to restrict competition among few sellers puts consumers at the mercy of collusive pricing and/or inefficient service. Under the EMR, a concentration is deemed to emerge when a non-temporary change of ownership and control results from any of two conditions: ${ }^{18}$

1) Merged operations of two or more previously undependent undertakings or parties to undertakings with the parties either dissolved as separate legal entities or one undertaking absorbs another and retains its legal identity in the merger, or

2) The acquisition by one or more persons already controlling at least one undertaking (or by one or more undertakings) of direct or indirect control of the whole or parts of one or more other undertakings through purchase of securities or assets by contract agreement or by any other means.

The EMR defines control, or the change of control, as constituted by rights, contracts or any other means which separately or in combination confer the possibility of exercising "decisive" influence on an undertaking through: ${ }^{19}$

1) Ownership or the right to use all or part of the assets of an undertaking;

2) Rights or contracts which confer decisive influence on the composition, voting or decisions of the organs of an undertaking.

Control is vested on persons or undertakings which are holders of the rights or entitled to rights under the contracts concerned, by virtue of having majority stockholdings for example. Alternatively, control may still be acquired by such parties even without being holders to such rights or entitlements when they are vested with derived power to exercise those rights. In some cases, evidence of indirect control through formal holders of rights may be inferred from information on shareholdings, contractual relations, source of financing or family links. ${ }^{20}$

\footnotetext{
${ }^{16}$ Slaughter and May, An Overview of EU Competition Rules (Slaughter and May, 2012)

${ }^{17}$ Consolidated Version of the Treaty on European Union and the Treaty on the Functioning of the European Union, 2012, OJEU Series C326/01, 2012

${ }^{18}$ Council Regulation (EC) No 139/2004 on the Control of Concentrations Between Undertakings (the EC Merger Regulation), 2004 OJEU Series L 24/1, 2004

${ }^{19}$ European Commission DG Competition, EU Competition Law: Rules Applicable to Merger Control. Situation as at 1 April 2010, 2010 (European Union, 2010) (EU Competition Law)

${ }^{20}$ EU Competition Law 


\section{Acquisition of Minority Shareholdings in EU Mergers}

Minority shareholdings are an increasing focus in merger control reviews in the EU, especially when such equity stake combined with other shareholders allow a change in control of the target company or enable the minority stockholder to block the adoption of strategic decisions which can be carried out through the exercise of veto rights. Even with a minority stake in the merger, such shareholders may still exercise de facto decisive influence over the target company.

There is at present an initiative to seek a review of the EMR, the guidelines that set forth merger control in the EU, in order to ensure better regulation this time with the aim of soliciting comments on what are seen as two main issues: ${ }^{21}$

1) The application of merger control rules to deal with the anti-competitive effects stemming from certain acquisitions of non-controlling minority shareholdings;

2) The effectiveness and smoothness of the case referral system from Member-States to the Commission both before and after the notification.

\section{Rationale for Merger Control in Non-Controlling Minority Shareholdings Acquisition}

Many merger review regimes extend merger control over share acquisitions that do not really constitute the purchase of outright majority of a target company in merger cases but where such minority acquisitions have the potential ability to exert a significant influence over the company. In Japan, separate notifications are already required for share acquisitions beyond $10 \%, 25 \%$ and 50\% shareholding levels. Canada requires merger review notification on merger cases involving acquisitions of more than $20 \%$ of the shares in public companies and more than $35 \%$ of the shares in private companies. ${ }^{22}$

Other than the acquisition share percentage test, other merger control regimes consider additional factors with which to assess whether minority equity stakes may result in giving such shareholders the ability to influence the business direction of mergers.

In Germany, for example, the Act Against Restraints of Competition (ARC) requires not only notification of any acquisition of $25 \%$ or more of the capital or voting rights of another undertaking, but also notification of acquisitions that fall below the specified $25 \%$ threshold to the extent that the transaction would enable the buyer to exercise "a competitively significant influence" over the target company. ${ }^{23}$

Under merger control guidelines in the United Kingdom, acquisitions of minority shareholdings between 10\%-15\% may be subject to merger review to the extend that such shareholdings may result in granting the ability to exercise "material" influence over the target company. The factors that will define what constitutes material influence range from whether the minority shareholder is accorded special voting rights or veto rights, board representation and/or financial interdependence. ${ }^{24}$

\footnotetext{
${ }^{21}$ European Commission, Towards More Effective EU Merger Control (Commission Staff Working Document, $\operatorname{SWD}(2013) 239$ final. Part 1/3, European Union 2013)

${ }^{22}$ International Competition Network, Defining Merger Transactions for Purposes of Merger Review (ICN, 2007)

${ }^{23}$ International Competition Network, Defining Merger Transactions for Purposes of Merger Review (ICN, 2007) (ICN Defining Merger Transactions)

${ }^{24}$ ICN Defining Merger Transactions
} 
In South Africa, notification requirements are in order for acquisitions of minority stakes when shareholder agreements or similar agreements give the buyer the ability to "materially influence" the business policy of the target company. ${ }^{25}$

Even for these merger review procedures on acquisitions involving minority shareholdings, exemptions are granted or rather special rules apply for share acquisitions mainly in financial services industry. Those shares acquired by securities underwriters as passive passive investments without intent to influence the target company and normally performed with a view to resell the investment within a year are generally exempt from merger review notification. This is true in the United States, South Africa and the EU. ${ }^{26}$

Ultimately, the attention given to minority shareholdings stems from the recognition that such shareholdings, even if of purely passive nature, may carry anti-competitive effects in certain situations. In particular, such minority interest may have the ability to influence the target company to compete less aggressively, or it may decide to behave less competitively so as not to affect its financial interest in the target company. There is therefore an urgency to consider whether merger control should cover as well to review minority shareholdings with respect to their tendency to undermine competition policy. ${ }^{27}$

\section{Merger Control Rules for Minority Shareholdings in the EU}

The European Commission has recognised that effective competition policy requires having the means to police and regulare all sources of harm to competition and consumers. The chief argument on the increasing focus on structural links, referring to the acquisitions of noncontrolling minority shareholdings in merger and acquisitions proposals, is that such equity participation may lead to anti-competitive stances that may lead to harmful welfare effects on consumers. That said, the European Commission acknowledges that the EU does not have the procedural resort to systematically prevent the anti-competitive effects coming from those structural links. ${ }^{28}$ Particular attention is given to the ability of the European Commission to extend merger control over acquisitions, especially with respect to acquisitions of minority shareholdings, in problematic merger cases of the horizontal nature (between competitors) or in vertical relationships (supply chain relationships).

In pacing its call for comments on the issue of merger control over minority shareholdings acquisition, the European Commission harps on established economic theory to support the anti-competitive effect that such structural links in mergers may imply in competition policy. There are said to be three ways by which structural links may lead to adverse competitive effect: ${ }^{29}$

1) Reduced competitive pressure between competitors (horizontal unilateral effects);

2) Substantially facilitating coordination, or collusion, among competitors (horizontal coordinated effects);

3) Allow companies to hamper competitors' access to inputs or customers in the case of vertical structural links (vertical effects).

\footnotetext{
${ }^{25}$ ICN Defining Merger Transactions

${ }^{26}$ International Competition Network, Defining Merger Transactions for Purposes of Merger Review (ICN, 2007)

${ }^{27}$ OECD, Definition of Transaction for the Purporse of Merger Control Review (DAF/COMP(2013)25)

${ }^{28}$ European Commission, Towards More Effective EU Merger Control (Commission Staff Working Document, SWD(2013) 239 final. Part 1/3, European Union 2013)

${ }^{29}$ European Commission, Towards More Effective EU Merger Control (Commission Staff Working Document, SWD(2013) 239 final. Part 1/3, European Union 2013)
} 


\section{Sole and Joint Control and Structural Links}

Under EMR clarificatory discussions, sole control is defined as having acquired when one undertaking alone exercises decisive influence on an undertaking. There is said to be sole control when the acquirer of such sole control in an undertaking enjoys the power to determine the strategic commercial decisions of the other undertaking. This normally is the result of acquiring majority of the voting rights in a company. The other case of sole control involves situation where only one shareholder is able to veto strategic decisions in an undertaking, but this shareholder does not have the power on his own to impose such decisions (known as negative sole control). Under these circumstances, a single shareholder holds the same level of influence as that enjoyed by an individual shareholder which jointly controls a company, that is, vested with th epower to block the adoption of strategic decisions. However, unlike in a jointly-controlled company, there are no other shareholders enjoying the same level of influence and the shareholder with the negative sole control does not have to cooperate with specific other shareholders in determining the strategic behaviour of the controlled undertaking. The ability of the negative sole control shareholder can produce a deadlock situation which enables it to have a decisive influence and therefore control of the undertaking as defined in the EMR.

\section{Sole Control}

Sole control is legally obtained where an undertaking acquires the majority of the voting rights of a company. An acquisition that does not include a majority of the voting rights does not automatically grant control even if it involves the purchase of a majority of the share capital. ${ }^{30}$ In cases where company statutes require a supermajority for strategic decisions, the acquisition of a simple majority of the voting rights may be insufficient to determine the strategic directions but sufficient to confer a blocking right on the acquirer (negative control).

In the presence of structural links, or the acquisition of minority shareholdings, sole control may be legally vested in situations where specific rights are attached to this shareholding. ${ }^{31}$ These rights may be tied up with preferential shares of stocks that enable even minority acquirers of such stockholdings to determine the strategic commercial behaviour of the target company. An example would be the power to appoint more than half of the members of the supervisory board or the administrative board.

It is also possible for a minority shareholder to exercise sole control when that shareholder is vested with the right to manage the activities of the company and to determine the business policy on the basis of the organisational structure (for example, as a general partner in a limited partnership which often does not even have a shareholding). ${ }^{32}$ A negative sole control may likewise occur in structural links when there is one shareholder owning $50 \%$ in an undertaking while the remaining $50 \%$ is held by several other shareholders, or where there is a supermajority required to enable strategic decisions which technically confers a veto right upon only one shareholder, whether that shareholder be a majority or a minority shareholder. ${ }^{33}$

A minority shareholder is considered to have sole control on a de facto basis when that shareholder is likely to achieve a majority at the shareholders' meetings, given the level of its

\footnotetext{
${ }^{30}$ Council Regulation (EC) No 139/2004 on the Control of Concentrations Between Undertakings (the EC Merger Regulation), 2004 OJEU Series L 24/1, 2004 (EC Merger Regulation)

${ }^{31}$ EC Merger Regulation

${ }^{32}$ EC Merger Regulation

${ }^{33}$ Council Regulation (EC) No 139/2004 on the Control of Concentrations Between Undertakings (the EC Merger Regulation), 2004 OJEU Series L 24/1, 2004 (EC Merger Regulation)
} 
shareholdings. Under EMR, such foreseeable gaining of sole control by structural links will be assessed in terms of how widely dispersed the remaining (non-majority) shares are, whether other important shareholders have structural, economic or family links with the larhe minority shareholder or whether other shareholders have a strategic or a purely financial interest in the target company.

\section{Joint Control}

Joint control can emerge when there is possibility of exercising decisive influence by two or more undertakings or persons over another undertaking, in this case the target company. Decisive influence is taken to mean the power to block executive actions which determine the strategic commercial behaviour of an undertaking. Joint control renders the possibility of a deadlock situation resulting from the power of two or more parent companies to reject proposed strategic decisions, especially when they are at opposite sides over strategic issues. As a result, it is imperative for these shareholders to come to a common understanding and cooperation scheme in order to determine the commercial policy of the joint venture. ${ }^{34}$

\section{Joint Control and Veto Rights of Minority Shareholders}

Joint control is one area of concern for merger control review to extend to minority shareholdings because of the possibility that it may lead to the exercise of decisive influence over executive decisions. This is because joint control may still arise even when there is no equality between the two parent companies in either votes or in representation in decisionmaking bodies or in cases where there are more than two parent companies. ${ }^{35}$ Here, the role of minority shareholdings may be crucial. There are cases when minority shareholders carry with their acquisition additional rights that allow them to veto decisions which are deemed essential for the strategic commercial behaviour of the joint venture. ${ }^{36}$ Such veto rights may be granted in the statute of the joint venture of conferred by agreement between its parent companies. Veto power may operate through the holding of a specific quorum required for decisions made at the shareholders' meeting or by the board of directors to the extent that the parent companies are represented on this board. It may also be that strategic decisions are subject to approval by a supervisory body where the minority shareholders are represented and form part of the quorum required to undertake the decision-making.

The relevant veto rights that can be vested on minority shareholders must be related to strategic decisions on the business policy of the joint venture and must go beyond those veto rights that normally go with such shareholdings to protect their financial interests as investors in the joint venture. Typically, this normal protection of the rights of minority shareholders is related to decisions such as changes in the statute, an increase or decrease in the capital or liquidation. An example of such veto right that does not confer joint control on minority shareholders is when it allows such shareholders to prevent the sale or winding-up of the joint venture. ${ }^{37}$

Those veto rights that confer joint control on minority shareholders cover those decisions on business issues like the budget, business plan, major investments or the appointment or senior management.

\footnotetext{
${ }^{34}$ EC Merger Regulation

${ }^{35}$ Council Regulation (EC) No 139/2004 on the Control of Concentrations Between Undertakings (the EC Merger Regulation), 2004 OJEU Series L 24/1, 2004 (EC Merger Regulation)

${ }^{36}$ EC Merger Regulation

${ }^{37}$ EC Merger Regulation 
As far as minority shareholdings are concerned, the acquisition of joint control does not require that the acquirer has the power to exercise decisive influence on the day-to-day management of the undertaking. Rather, what is crucial is that the veto rights are sufficient to enable the parent companyies to exercise such influence in relation to the strategic business behaviour of the joint venture. ${ }^{38}$ In addition, it is not necessary to establish that an acquirer of joint control in the joint venture will actually make use of its decisive influence. The mere possiblity of exercising such influence and the mere existence of the veto rights is sufficient to establish decisive influence at the strategic level.

Accordingly, in order for a minority shareholder to acquire joint control, it is not necessary to have all the veto rights mentioned above. It may be sufficient that only some or even only one such right exists. The precise content of the veto right itself and its importance in the context of the specific business of the joint venture will determine if it is sufficient or not. ${ }^{39}$

\section{Joint Exercise of Voting Rights of Minority Shareholders}

Under the EMR, two or more undertakings that acquire minority shareholdings may still obtain joint control even in the absence of specific veto rights. This happens when the combined minority shaeholdings provide the means for controlling the target undertaking. This means that when combined, minority shareholders will gain the majority of the voting rights and will act together in exercising these rights. This can result from a legally binding agreement or it may be established on a de facto basis.

The legal manner of obtaining joint exercise of voting rights may be in the form of a jointlycontrolled holding company to which the minority shareholders can transfer their rights, or an agreement by which they undertake to act in the same way (pooling agreement).

In rare cases, collective action can occur on a de facto basis where strong common interests exist between the minority shareholders so that they would not act against each other in exercising their rights in relation to the joint venture. However, this will be less likely when there is a greater number of parent companies involved in the joint venture. ${ }^{40}$

Minority shareholders may exercise joint control when there is a high degree of dependency of a majority shareholder on a minority shareholder. This happens when the joint venture depends economically and financially on the minority shareholder, or where only theminority shareholder has the required know-how for the operation of thejoint undertaking while the majority shareholder is only a financial investor. ${ }^{41}$ Under these circumstances, the majority shareholder may notbe able to enforce its position, but the joint venture partner may be able to block strategic decisions so that both parent undertakings are required to cooperate permanently. This leads to a de facto situation where joint control prevails over legal arrangements under which the majority shareholder would have sole control.

\footnotetext{
${ }^{38}$ Council Regulation (EC) No 139/2004 on the Control of Concentrations Between Undertakings (the EC Merger Regulation), 2004 OJEU Series L 24/1, 2004 (EC Merger Regulation)

${ }^{39}$ EC Merger Regulation

${ }^{40}$ Council Regulation (EC) No 139/2004 on the Control of Concentrations Between Undertakings (the EC Merger Regulation), 2004 OJEU Series L 24/1, 2004 (EC Merger Regulation)

${ }^{41}$ EC Merger Regulation
} 


\section{Structural Links Case 1: Aer Lingus vs Ryanair}

The case of Aer Lingus and the acquisition of minority shares of stock by Ryanair is a landmark example of the limitations of current EU merger control procedures ${ }^{42}$. By official recount, Ryanair had acquired a significant non-controlling minority stake in Aer Lingus' outstanding share capital when Ryanair notified in 2006 the proposed acquisition of control of Aer Lingus in a parallel move. The European Commission prohibited the acquisition of control in June 2007, after having considered the serious competition harm that would result from the merger. However, after the European Commission's prohibition, Ryanair maintained a minority stake in Aer Lingus representing 29.4\% of outstanding share capital. Because the EMR only provides ex ante review of operations leading to the acquisition of control, the European Commission was proscribed from enforcing applicable remedies under EU merger control procedures against the minority shareholdings of Ryanair in Aer Lingus. This reasoning was confirmed in 2010 by the General Court. ${ }^{43}$ Even then, Aer Lingus had argued that Ryanair's minority stake would have significant negative effects on competition between the two air passenger carriers. Ryanair was said to have used its minority stake to obtain access to Aer Lingus' confidential strategic plans and business secrets, block special resolutions and request extraordinary general meetings with the intent to reverse already-adopted strategic decisions. The idea presented is that Ryanair's minority shareholdings effectively weakened Aer Lingus' capacity to be an effective competitor of Ryanair. On the other hand, Ryanair's value of its investment in Aer Lingus could have reduced Ryanair's incentive to compete effectively.

\section{Structural Links Case 2: Siemens vs VA Tech}

A second case involves the acquisition by Siemens of a minority stake in SMS Demag, a competitor of VA Tech in the market for metal plant building. ${ }^{44}$ Here, the European Commission found competition threatened at the horizontal level. Even as Siemens had already exercised a put option to sell its stake in SMS Demag, the sale had not yet become effective due to on-going litigation. The European Commission found that the influence which Siemens had via the still existing minority on the competitive conduct of SMS Demag could reduce competition in this highly concentrated market. The European Commission approved the merger following a commitment by Siemens to transfer its rights as shareholder of SMS Demag to a trustee pending the divestiture.

\section{Structural Links Case 3: IPIC vs MAN Ferrostaal}

The case of IPIC and MAN Ferrostaal in the Eurotecnica merger is an example of a vertical merger concern for the European Commission. ${ }^{45}$ MAN Ferrostaal acquired minority participation in Eurotecnica, which is an important supplier of a licence and engineering services essential for the parties' and third parties chemical production. The remedy applied to this merger control issue and so pave way for the merger was to secure IPIC's commitment to divest its participation in Eurotecnica.

\section{Options for the European Commission}

Within the EU, it is generally acknowedged that the existing merger control regime is inadequate to deal with the participation of minority shareholdings in mergers and

\footnotetext{
${ }^{42}$ Pedro Caro de Sousa, Minority Shareholdings and the Competing Merger Control Jurisdictions of the EU and National Competition Authorities: The Ryan Air / Aer Lingus Case (Competition Policy International, 2012)

${ }^{43}$ European Commission, Towards More Effective EU Merger Control (Commission Staff Working Document, SWD(2013) 239 final. Part 1/3, European Union 2013)

${ }^{44}$ European Commission, Towards More Effective EU Merger Control (Commission Staff Working Document, SWD(2013) 239 final. Part 1/3, European Union 2013)

${ }^{45}$ European Commission, Towards More Effective EU Merger Control (Commission Staff Working Document, SWD(2013) 239 final. Part 1/3, European Union 2013)
} 
acquisitions that otherwise would apply for merger review. In fact, the European Commission's ability to use Article 101 or 101 of the TFEU to intervene against anti-competitive structural links, or those minority shareholder interests, is limited and even then does not cover all categories of anti-competitive structural links. In the past, the Court of Justice has ruled that structural links may fall under Article 101 of the TFEU and yet it is still unclear under which circumstances a structural link may constitute an agreement that carries the intent or effect of restricting competition within the context of Article 101 of the TFEU, especially when the structural link is set up through acquisition of a series of shares in the stock exchange. ${ }^{46}$

On the other hand, the requirements that are outlined in Article 102 of the TFEU, where the acquiring undertaking should already be dominant and that the acquisition should be a case of abuse of dominance, only allows the European Commission a very narrow jurisdiction over deals that may result to competitive harm arising from such minority shareholdings.

Accordingly, two options for a review of merger control rules applying to minority shareholdings are considered:

1. Extend the current system of merger control review to minority shareholdings.

2. This option requires that all relevant acquisitions of minority shareholdings be notified in advance to the Commission and would not be implemented before the Commission has cleared them. The Commission would decide in each case under a notification system whether or not the transaction could be authorised.

Allow the European Commission to have the discretion to select cases of critical minority shareholdings for investigation.

This second option could either be achieved by a self-assessment system, where obligation to notify a transaction to the Commission in advance would not apply to structural links, but instead the parties would be allowed to proceed with the transaction. The European Commission would have the option whether and when to open an investigation. The Commission would have discretion to investigate such structural links under the selfassessment system, but would have to rely on own market intelligence or complaints to become aware of structural links that may raise competition issues.

It is proposed that the substantive test laid out in the EMR for the examination of full mergers, that is, determining whether such merger transactions do significantly impede effective competition, should apply to acquisition of or participation of minority shareholdings, with additional clarification in the relevant European Commission guidelines. ${ }^{47}$ As far as joint ventures are concerned, the European Commission should also be able to assess whether the structural link has the object or effect of coordinating or influencing the parent companies' conduct. If and when this is the case, such coordination should be assessed as infringement of the rules under Article 101 of the TFEU similar to the requirement under Article 2(4) of the EMR.

In any event, the turnover thresholds that are already set forth in the EMR as guidelines to establish the European Commission's jurisdiction over full merger control cases should be applicable as well to cases involving minority shareholdings.

\footnotetext{
${ }^{46}$ European Commission, Towards More Effective EU Merger Control (Commission Staff Working Document, SWD(2013) 239 final. Part 1/3, European Union 2013)

${ }^{47}$ European Commission, Towards More Effective EU Merger Control (Commission Staff Working Document, SWD(2013) 239 final. Part 1/3, European Union 2013)
} 


\section{CONCLUSION}

Even with a few Member-States already having enforced procedures on the influence of minority shareholdings on merger control issues, there is still much reworking of merger control procedures to be done at the EU level. Lengthy discussions on the impact of minority shareholdings and their possible influence on the strategic directions and control in target companies or proposed mergers have shown the many different ways such a minority shareholding can actually undermine competitive practice and competition policy on the whole. This explains current initiatives to give teeth to the European Commission to effectively address, as it has for majority shareholdings in mergers and acquisitions and in full joint ventures, the role that minority shareholders are foreseen to play in proposed mergers that in any way may be construed or likely to result in the restriction of competition, the kind that is disadvantageous to consumers and the general public.

\section{Bibliography}

Bonde, Jens-Peter, ed, The Lisbon Treaty: The Readable Version (Foundation for EU Democracy, 2008)

Burnside, A, Minority Shareholdings: An Overview of EU and National Case Law (e-Competitions No. 56676, Cadwalader Wickersham \& Taft LLP, 2013)

Caro de Sousa, P, Minority Shareholdings and the Competing Merger Control Jurisdictions of the EU and National Competition Authorities: The Ryan Air / Aer Lingus Case (Competition Policy International, 2012)

Commission Implementing Regulation (EU) No. 1269/2013 Amending Regulation (EC) No 802/2004 Implementing Council Regulation (EC) No 139/2004 on the Control of Concentrations Between Undertakings, 2013, OJEU L 336/1 2013

Consolidated Version of the Treaty on European Union and the Treaty on the Functioning of the European Union, 2012, OJEU Series C326/01, 2012

Council Regulation (EC) No 139/2004 on the Control of Concentrations Between Undertakings (the EC Merger Regulation), 2004 OJEU Series L 24/1, 2004

European Commission, The Efficiency Defence and the European System of Merger Control (European Economy, Reports and Studies, European Union, 2001)

European Commission, Towards More Effective EU Merger Control (Commission Staff Working Document, SWD(2013) 239 final. Part 1/3, European Union 2013)

European Commission DG Competition, Best Practices on the Conduct of EC Merger Control Proceedings (European Union, 2004)

European Commission DG Competition, Communication from the Commission to the Council. Report on the Functioning of Regulation No. 139/2004 (European Union, 2009)

European Commission DG Competition, EU Competition Law: Rules Applicable to Merger Control. Situation as at 1 April 2010, 2010 (European Union, 2010)

European Commission DG Economic and Financial Affairs, Mergers and Acquisitions Note (European Commission, 2005)

Galloway, J. Convergence in International Merger Control (The Competition Law Review 5/2/179-192, July 2009) $<$ http://www.clasf.org/CompLRev/Issues/Vol5Iss2Art2Galloway.pdf $>$ accessed 12 April 2014

ICT Regulation Toolkit, Anti-Competitive Conduct (infoDev and the International Telecommunication Union, 2014) <http://www.ictregulationtoolkit.org/2.2> accessed 12 April 2014

International Competition Network, Defining Merger Transactions for Purposes of Merger Review (ICN, 2007) $<$ http://www.internationalcompetitionnetwork.org/uploads/library/doc327.pdf> accessed 12 April 2014

Kar, N and Pollard, M, Navigating Global Merger Control (International Financial Law Review, Euromoney, 2014) <http://www.iflr.com/Article/3315233/Navigating-global-merger-control.html> accessed 12 April 2014 
Organisation for Economic Co-operation and Development Directorate for Financial and Enterprise Affairs Competition Committee, Anti-Trust Issues Involving Minority Shareholdings and Interlocking Directorates, (OECD DAF/COMP(2008)30, 2009)

Organisation for Economic Co-operation and Development Directorate for Financial and Enterprise Affairs Competition Committee, Definition of Transaction for the Purpose of Merger Control Review (OECD DAF/COMP(2013)25, 2013)

Rill, J and others, Coordinated Effects Analysis Under International Merger Regimes (ICN Report on Merger Guidelines- Chapter 4, International Competition Network, 2004)

<http://www.internationalcompetitionnetwork.org/uploads/library/doc560.pdf> accessed 12 April 2014

Robinson, S and Zerdin, M, The Mergers and Acquisitions Review: European Overview, 7th edition, (Law and Business Research Ltd., 2013) < https://www.slaughterandmay.com/media/2082926/the-mergers-and-acquisitionsreview-european-overview.pdf> accessed 14 April 2014

Slaughter and May, An Overview of the EU Competition Rules (Slaughter and May, 2011)<https://www.slaughterandmay.com/media/64569/an-overview-of-the-eu-competition-rules.pdf> accessed 12 April 2014

Slaughter and May, The EU Merger Regulation: an Overview of the European Merger Control Rules (Slaughter and May, 2012) <https://www.slaughterandmay.com/media/64572/the-eu-merger-regulation.pdf> accessed 12 April 2014

Veugelers, R, Tackling Innovation in EU Merger Control (Bruegel Policy Contribution 2012/04, 2012)

Wikipedia, Merger Control (wikipedia, 2013) <http://en.wikipedia.org/wiki/Merger_control> accessed 12 April 2014

Winterscheid, J, Defining Merger Transactions for Purposes of Merger Review (International Competition Network, 2007) 